\title{
The Scandinavian Intervention
}

\author{
ALEX WOOLF
}

FOLLOWING the introduction of Christianity in Late Antiquity the next major phase in Irish history resulted from the interaction between native Irish and Scandinavians, and, subsequently, the development of communities of Scandinavian origin established within Ireland and her peripheral territories (such as the Scottish islands, south-west Scotland, north-west England, the Isle of Man and coastal Wales). These interactions began as part of the wider phenomenon of Scandinavian diaspora in what is often termed the Viking Age. The concept of a Viking Age is not entirely unproblematic since, as Scandinavian archaeologists have argued, its beginnings, usually dated to the 790s, do not correspond to any major changes in domestic Scandinavian society. ${ }^{1}$ Indeed, the widely accepted chronological brackets of the Viking Age, c.790-1066, are derived entirely from the English experience, with the earliest recorded raid on Lindisfarne in 793 and the Battle of Stamford Bridge, in which the Norwegian king Harald Hardrada was slain in September 1066, providing the book-ends. It is thus questionable whether they should be exported to other countries. Even for England this chronology is tendentious, since although the raid on Lindisfarne may well be the earliest firmly dated Scandinavian attack, the Norwegian invasion of 1066 was followed up over the next decade by more than one Danish invasion under Sven Estridsson and the Domesday survey of 1086 seems to have been prompted by a planned invasion by Sven's son Cnut the Holy. Later still, Earl Hugh of Shrewsbury was killed by Scandinavian raiders in 1098. The concept of a discrete Viking Age can also be critiqued on the grounds that the invasions led by national kings leading national armies of the eleventh century were very unlike anything

1 B. Myhre, 'The Beginning of the Viking Age - Some Current Archaeological Problems', in A. Faulkes and R. Perkins (eds.), Viking Revaluations (London: Viking Society, 1993), 182203. I would like to thank Lesley Abrams and Helen Foxhall Forbes for reading this chapter in draft and supplying comments and references. Errors and eccentricities remain my own. 


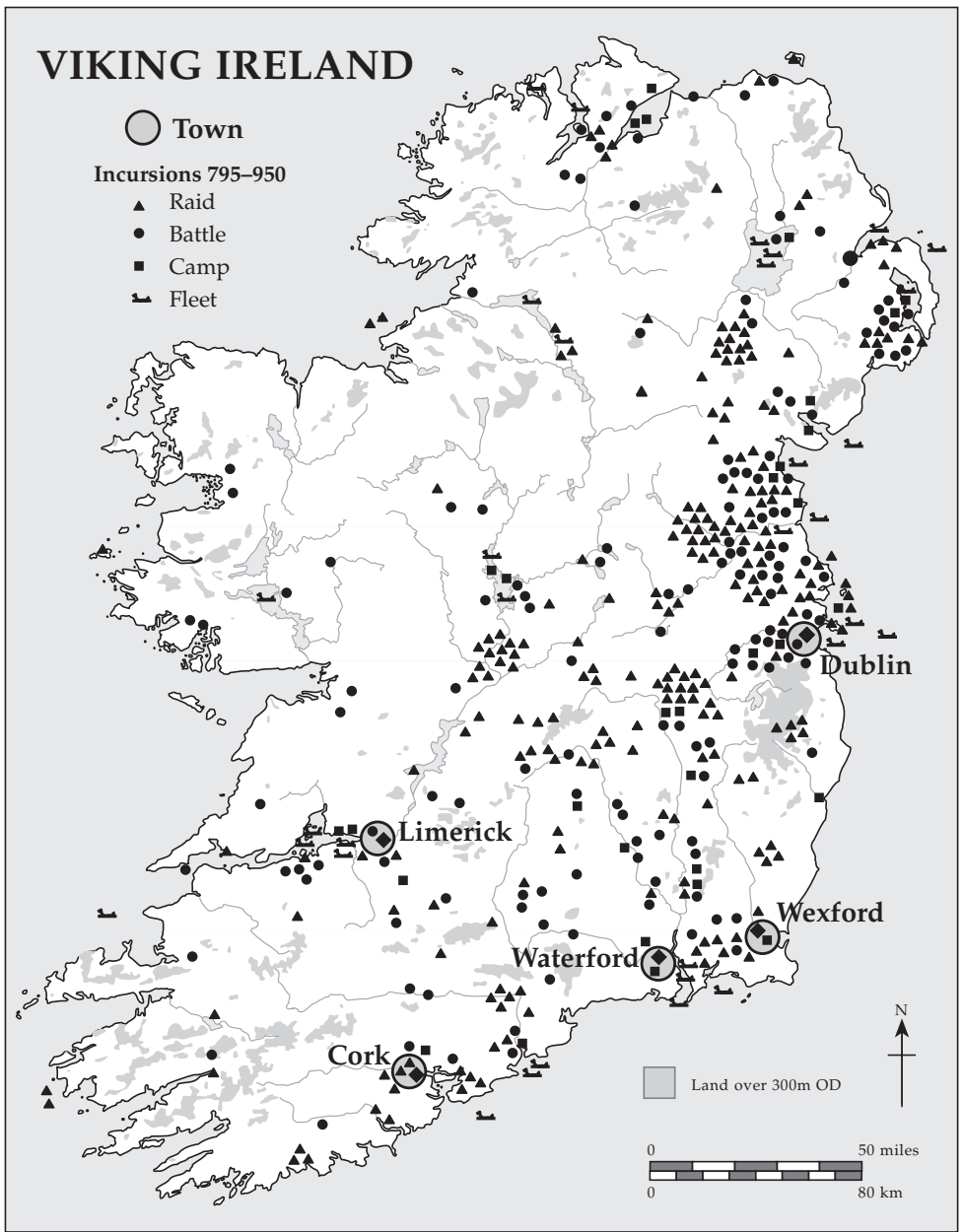

MAP 6. The Viking Intervention. Courtesy of Matthew Stout, School of History and Geography, DCU.

that had occurred earlier. Indeed, the earlier centuries of the Viking Age can also be broken down into numerous distinct phases (see Map 6).

Within Irish historiography the Battle of Clontarf, fought in April 1014, has fulfilled a similar role to Stamford Bridge as the 'final defeat of the vikings' but in reality it was no such thing. Sitriuc, the Scandinavian king of Dublin, remained in control of the city after the battle and continued to rule there for a further twenty years or so. The posthumous victor of the battle, Brian 
Bórama [Boru], certainly did have a military career that was transformative within Irish history; however, its legacy was not the defeat of the vikings but the ending of the Uí Néill [O’Neill] monopoly on claims to the kingship of Ireland. From his time until the Anglo-Norman conquest, the kingship of Ireland was claimed and disputed by dynasts from all the provinces of Ireland, not simply by branches of the descendants of Niall of the Nine Hostages. $^{2}$

Perhaps more significant than Clontarf in curtailing the aspirations of the Dublin dynasty to dominate Ireland was the Battle of Tara, fought in 980, a generation earlier, in which Sitriuc's father, Olaf Cuarán, was defeated by Máel-Sechnaill of Meath. ${ }^{3}$ This said, the Dubliners and their allies who fought at Tara, and indeed at Clontarf, were very different in identity, origins and aspirations from the earliest raiders of the 790s. Sitriuc and Olaf, despite their ultimate paternal ancestry, were probably both natives of Ireland and were certainly Christians whose kinship networks were deeply intertwined with those of their contemporary Irish kings. ${ }^{4}$ Their descendants continued to play an important part in Irish history up to and beyond the Anglo-Norman invasion. ${ }^{5}$

This chapter describes the changing nature of the Scandinavian contribution to the history of Ireland from the initial attacks $c .800$ through to the twelfth century. Topics covered will include the motivation for those first expeditions, the establishment of Ireland's first towns, the changing nature of those communities, the rate at which, and extent to which, a distinct Hiberno-Norse identity emerged, and the extent to which continued influx from Scandinavia influenced their development. The transformative nature of the interaction between the Scandinavians and the natives across Irish society, particularly in relation to slavery, will also be explored. I will avoid over-using the 'v-word', since 'viking' was not a commonly used early medieval term, and its meaning and etymology are far from clear. It appears both as a personal name and as a verb which seems to mean something like 'engaging in piracy' as well as a

2 M. Ní Mhaonaigh, Brian Boru: Ireland's Greatest King? (Stroud: Tempus, 2007); S. Duffy, Brian Boru and the Battle of Clontarf (Dublin: Gill \& Macmillan, 2013).

3 A. Woolf, From Pictland to Alba, 789-1070 (Edinburgh University Press, 2007), 214-16.

4 A. Woolf, 'Amláib Cúarán and the Gael, 941-81', in S. Duffy (ed.), Medieval Dublin III (Dublin: Four Courts Press, 2002), 34-42; H. B. Clarke, 'King Sitriuc Silkenbeard: A Great Survivor', in Clarke and Johnson (eds.), Vikings in Ireland and Beyond, 253-67.

5 S. Duffy, 'Irishmen and Islesmen in the Kingdoms of Dublin and Man, 1052-1171', Ériu, 43 (1992), 93-133; S. Duffy 'The Royal Dynasties of Dublin and the Isles in the Eleventh Century’, in S. Duffy (ed.), Medieval Dublin VII (Dublin: Four Courts Press, 2006), 51-65. 
common noun for someone involved in that activity. It was certainly not an ethnic label and owes its popularity as a catch-all descriptor to eighteenth-century romanticism. Its over-use in modern times has created an unhelpful image of a homogeneous cultural identity over several hundred years and thousands of square miles. It is much more helpful to consider the various cultural phenomena in their local contexts. ${ }^{6}$

\section{Scandinavian Identity and Motivations}

The core of Scandinavian identity in the early Middle Ages was a shared language and those aspects of oral culture that went with that shared language. The Scandinavian language, or cluster of dialects, began to emerge in the period c.400-700 as the Germanic dialect continuum of north-central Europe began to polarise into two clusters, a northern one, the ancestor of Scandinavian, and a western group ancestral to modern English, Dutch and German. $^{7}$ These clusters probably reflect the competing attraction of the two most successful Germanic-speaking courts of the time; that of the Franks, established in northern Gaul and the Rhineland, and that of the Danes, based on the islands of the western Baltic and the province of Skåne (part of Sweden since 1658). The Danish kingdom was less powerful than the Frankish but within its region was nonetheless overwhelmingly significant. In contrast to the modern stereotype of Scandinavian landscape, which draws on images of the fjords of western Norway, the Danish islands and Skåne in many ways more closely resemble the Irish east midlands or East Anglia, relatively flat rolling countryside comprising fertile fields separated by bosky hedgerows. This landscape had been settled for millennia and the islands had been cleared of bears, wolves and other such beasts long before the Viking Age. It was anything but wild. This Danish heartland was far more populous than any other region of Scandinavia, indeed its population probably exceeded that of the rest of Scandinavia put together, and since the last centuries вс it had supported a relatively stable settlement hierarchy and presumably political structures to match. Across Scandinavia as a whole, local ecologies, subsistence strategies, settlement patterns and funerary customs varied enormously but the presence of a wealthy elite class of Danish aristocrats provided a model for emulation and a potential source of patronage. Their geographical location also gave the

6 For a discussion of the term, see J. Jesch, Ships and Men in the Late Viking Age: The Vocabulary of Runic Inscriptions and Skaldic Verse (Woodbridge: Boydell Press, 2001), 44-56.

7 M. P. Barnes, 'The Scandinavian Languages in the Viking Age', in S. Brink (ed.), The Viking World (London: Routledge, 2008), 274-80. 
Danes the ability to control most of the exotic goods travelling north from Western and Central Europe, including wine, high-quality weapons, fine textiles and so forth. This central position of the Danes was one of two major factors contributing to Scandinavian identity, providing a hub, as it were, around which the other groups of North-Germanic speakers circled. ${ }^{8}$ The other major factor was the outer world, particularly those regions where Germanic was not spoken such as the Gaelic-speaking West, the Slavic-speaking south-east and the Finnish-speaking north-east and of course Romance-speaking Europe beyond the Franks. On journeys into these regions Scandinavian-speakers from different and quite distinct regions, who might have felt they had little in common while in the North, will have recognised shared elements in their identity and culture when surrounded by speakers of alien tongues. Thus, to some extent, the expansion of the Viking Age may have helped the Scandinavians to discover themselves and to create or reinforce a common identity. ${ }^{9}$

A number of factors contributed to the expansion out of the Scandinavian homelands in the late eighth and early ninth centuries. While the Danes controlled access to the North Sea trading network, largely operated by Frisians, which linked Scandinavia to the Frankish and Anglo-Saxon worlds, the most northerly Scandinavians traded, via the Russian rivers, with the Islamic World; exporting furs, amber and fair-skinned slaves in return for silver. This silver was then used to engage in commerce via the Danish and Frisian networks that could bring Rhenish wine and sword blades to the North. The earliest raids on northern Britain and Ireland seem to have resulted from disruption to these networks which had ensured relative stability through the eighth century. A combination of fluctuations in the silver supply coming from the east, due to political crises in the Caliphate, and increased Frankish royal intervention in Frisia and Saxony, the Danes' southern neighbours, created economic instability which prompted not only direct military conflict between Danish and Frankish kings but also from the most marginalised Scandinavian communities, those in western Norway, desperate attempts to find new and more reliable sources of wealth. ${ }^{10}$

8 For the rise of the Danish kingdom: U. Näsman, 'The Ethnogenesis of the Danes and the Making of a Danish Kingdom', Anglo-Saxon Studies in Archaeology and History, 10 (1999), 1-10; M. Axboe, 'Towards the Kingdom of Denmark', Anglo-Saxon Studies in Archaeology and History, 10 (1999), 109-18.

9 For the impact of the diaspora on the appearance of a Scandinavian identity: L. Abrams, 'Diaspora and Identity in the Viking Age', Early Medieval Europe, 20.1 (2012), 17-38; J. Jesch, The Viking Diaspora (London: Routledge, 2015), appeared too late to be fully consulted in the writing of this chapter.

10 J. H. Barrett, 'What Caused the Viking Age?', Antiquity, 82 (2008), 671-85. 
It is unlikely that the Norwegian Westlanders 'discovered' the lands 'West Overseas' in this period. Shetland is extremely close to Norway (Bergen is the nearest railway station to Lerwick, the island's capital) and it is implausible that the populations of both these territories, who had long depended on boats for their livelihood, were not aware of the land just beyond the horizon. There had probably been sporadic contact since the Bronze Age. What had changed was motivation. For most of prehistory the northern parts of Scotland, with which Scandinavians might have been familiar, probably had little to offer. They had a sparse population, poor agricultural potential and a low level of material wealth. What had changed between the sixth century and the ninth, however, was the arrival of Christianity and innovative Christian institutions, largely spreading up the west coast from Ireland, famously to places such as Iona, Applecross and Lismore but also to undocumented sites such as those discovered by archaeological investigation at Portmahomack in Easter Ross, Birsey on Orkney or St Ninian's Isle and Papil on Shetland. Shetland was no longer a remote and unappealing timberless land of sheep-farmers and fishermen, miles from anywhere, but a gateway into a world beyond connecting western Scandinavia, on the fringes of Europe, with wealthy and exotic places such as Armagh, Clonmacnoise and Monkwearmouth-Jarrow, the great 'monastic cities' of the Insular World. For the hardy sea-faring inhabitants of western Norwegian territories like Hordaland and Møre, directly accessing this new source of wealth must have seemed preferable to the unreliable trickledown of southern silver which came to them via Danish- and Swedish-controlled networks to the south and east. ${ }^{11}$ This, then, is almost certainly the context for the earliest raids, a search for start-up capital, in slaves and precious metals, which would allow the raiders to enter into trading relations that would bring them wine, weapons and fancy clothing from the Frankish Empire. The Danes, on the other hand, had become increasingly involved in direct conflict with the Franks over Saxony and particularly Frisia and this had led to Frankish intervention in internal Danish politics resulting in a series of coups and civil conflicts. The losers in these conflicts, often accompanied by large fleets of supporters, began to engage in larger-scale military activity in Gaul and England. ${ }^{12}$ Thus even in

11 M. Heen-Pettersen, 'Insular Artefacts from Viking-Age Burials from mid-Norway: A Review of Contact between Trøndelag and Britain and Ireland', Internet Archaeology, 38 (2014) http:/ / dx.doi.org/10.11141/ia.38.2.

12 For Danish-Frankish relations see K. L. Maund, 'Turmoil of Warring Princes: Political Leadership in Ninth-Century Denmark’, HSJ, 6 (1994), 29-47. 
its earliest phase, 'viking' activity had at least two distinct origins and sets of characteristics.

\section{Raids and Settlement}

Scholars working on the activities of Viking-Age Scandinavians in Ireland have over the past decade or so begun to re-assess their views about the rate at which sporadic raiding turned into settlement. The traditional view was that serious settlement began in the 840s but in the last few years new archaeological discoveries and re-examination of some of the chronicle records has led this view to be questioned. As early as 798, we are told that a group of heathens burned Inis Pátraic (County Dublin) and 'took the cattle tribute from the territories'. This last detail does not sound like an element in a smash and grab raid. It is unlikely that large numbers of cattle could have been taken away on ship-board and so the extraction of cattle tribute was more likely intended for local consumption over a period of time. This suggests that the 'raiders' were perhaps based for several months, at least, somewhere in the Dublin area. Developer-funded archaeology in and around Dublin has also begun to uncover Scandinavian-style burials with carbon-14 dates centring on the late eighth or very early ninth centuries. As more such evidence is recovered and analysed it may well be that we have to revise received ideas about the origins of Scandinavian settlement in Ireland..$^{13}$

Whatever the precise chronology, by the middle of the ninth century longterm and in some cases permanent (as it transpired) Scandinavian settlements began to appear in Ireland. This type of settlement, termed longphuirt (singular longphort) in the scholarly literature, was not introduced from Scandinavia but developed in the colonial context. The most famous of them became the medieval and modern cities of Dublin, Limerick and Waterford, but a number of others are mentioned in contemporary annals and yet more have begun to be identified in the archaeological record and investigated. ${ }^{14}$ The best known and largest of these is the site known as Woodstown, located upstream of Waterford on the south bank of the River Suir. This site was almost certainly

13 L. Simpson, 'The First Phase of Viking Activity in Ireland: Archaeological Evidence from Dublin', in Sheehan and Ó Corráin (eds.), Viking Age in Ireland, 418-29.

14 E. P. Kelly, 'The longphort in Viking-Age Ireland: The Archaeological Evidence', in Clarke and Johnson (eds.), Vikings in Ireland and Beyond, 55-92. For a critical approach see S. H. Harrison, 'Beyond longphuirt? Life and Death in Early Viking-Age Ireland', in D. M. Hadley and L. ten Harkel (eds.), Everyday Life in Viking-Age Towns: Social Approaches to Towns in England and Ireland, c.800-1100 (Oxford: Oxbow, 2013), 61-72; J. Sheehan, 'The Longphort in Ireland', Acta Archaeologica, 79 (2008), 282-95. 
a precursor to Waterford, though there are no certain annalistic references to it, and initial investigation suggests that it was occupied from the mid-ninth to the mid-tenth century. Sites like Woodstown, which did not develop into later towns, are particularly useful as they give us an opportunity to assess the early layout of Scandinavian settlements in Ireland. ${ }^{15}$ The ground-plans of these longphuirt, while making allowances for local topography, seem to have been fairly consistent. Their principal initial function seems to have been to protect the ships of the invaders while plundering expeditions were made overland, presumably on captured ponies. Consequently they mostly conform to a plan comprising a D-shaped ditch and bank (probably originally surmounted by a palisade) enclosing a significant stretch of shelving river bank, in the case of Woodstown some $500 \mathrm{~m}$. Some seem to have been occupied for very brief periods, perhaps as little as a few days or weeks, others on what must have seemed a permanent basis and yet others, perhaps, periodically revisited. Most seem to have been located on or very near to pre-existing political boundaries, either exploiting under-utilised march land or perhaps established in collaboration with one of the neighbouring kingdoms in return for shared defence, or aggression, against the other.

The story of Hiberno-Norse settlements can be characterised as the evolution of pirate bases into medieval cities. Whilst few scholars would disagree with this notion in its broadest terms, there has been much debate about certain aspects of this evolution. Was it, for example, gradual or should archaeologists be able to pinpoint the moment at which a particular settlement became a 'real' town? ${ }^{16}$ The debate has at times become polarised between those who see the Scandinavian colonists as principally traders and those who see them as principally raiders. ${ }^{17}$ Increasingly, however, the inextricable relationship between these two activities has been recognised. As noted above, when discussing the motivation for raiders coming from the Norwegian Westland, predation was principally undertaken for the purpose of accruing

15 I. Russell and M. F. Hurley (eds.), Woodstown: A Viking-Age Settlement in Co. Waterford (Dublin: Four Courts Press, 2014).

16 H. B. Clarke, 'Proto-Towns and Towns in Ireland and Britain in the Ninth and Tenth Centuries', in Clarke et al. (eds.), Ireland and Scandinavia, 331-80; D. M. Hadley and L. ten Harkel, 'Preface', in Hadley and ten Harkel (eds.), Everyday Life in Viking-Age Towns, vii-xii.

17 For a study emphasising trade: M. A. Valante, The Vikings in Ireland: Settlement, Trade and Urbanization (Dublin: Four Courts Press, 2008). For a somewhat bloodier perspective: D. N. Dumville, The Churches of North Britain in the First Viking Age (Whithorn: Whithorn Trust, 1997); A. P. Smyth, 'The Effect of Scandinavian Raiders on the English and Irish Churches: A Preliminary Reassessment', in Smith (ed.), Britain and Ireland, $1-38$. 
start-up capital that could be used to engage in trade. The most sought-after commodities in Scandinavian communities, such as wine, high-quality weapons, silver, and fine textiles, were not, by and large, available in places like Ireland and Britain, but had to be obtained from much more developed economies such as those of the Frankish Empire or the Islamic Caliphate. These polities, however, had an unceasing demand for cheap labour, and thus slaves, captured or purchased from less powerful polities, could be used to engage in trade with the economic superpowers of the day. ${ }^{18}$

For most of the ninth and tenth centuries, the basic currency in use amongst Scandinavians, at home and abroad, was bullion, often in the form of what modern scholars term hack-silver. Hack-silver is made up of fragments of silver artefacts, including ingots and fragmentary coins, which have been chopped up into small pieces to allow them to function as currency. Because, unlike coins, these fragments are not standard weights, sizes and values, those engaging in hack-silver economic practices also require scales and standardised weights. Complete coins were also used in this bullion economy but were valued purely by weight and purity of silver content rather than for any notional 'face value'. ${ }^{19}$ Fragments of hack-silver, scales and weights and coins were recovered scattered across the interior of the Woodstown enclosure, the most intensively investigated of the longphort sites. This phenomenon has given support to the view that trade and exchange was a major function of these sites even before they began to transform into fully fledged towns. It should be noted that the coins from the site were all Anglo-Saxon and Islamic. Coinage of this sort is very rare in pre-Viking-Age Ireland and thus it is likely that it was brought into the country by the Scandinavians. The same seems to be the case with the hack-silver, much of which derives from artefacts fashioned overseas. Some of the silver, however, would appear to derive from ingots smelted on the site itself and its ultimate provenance is thus unclear (most silver circulating in northern Europe came from elsewhere and had often been melted down and refashioned several times before

18 M. McCormick, The Origins of the European Economy: Communications and Commerce, $A D$ 300-900 (Cambridge University Press, 2001), 729-77; M. McCormick, 'New Light on the "Dark Ages": How the Slave Trade Fuelled the Carolingian Economy', Past and Present, 177 (2002), 17-54.

19 B. Hårdh, Silver in the Viking Age: A Regional Economic Study (Stockholm: Almquist and Wiksell International, 1996); J. Graham-Campbell, " "Silver Economies" and the NinthCentury Background', in J. Graham-Campbell, S., M. Sindbæk and G. Williams (eds.), Silver Economies, Monetisation and Society in Scandinavia, AD 800-1100 (Aarhus University Press, 2011), 29-40. 
entering the archaeological record in whatever form it survives in today). ${ }^{20}$ What is significant about this is that whilst the popular image is of vikings stripping Ireland of her material wealth, the archaeological evidence would seem to indicate that the Scandinavians were in fact net importers of precious metal into the country. With regard to the currency function of this material, attested by the presence of scales and weights, an important question is whether the exchange it attests to was principally between Scandinavians and native Irish or simply amongst the Scandinavians themselves.

\section{Slavery}

Due to the objectification of Scandinavians in Ireland simply as vikings, and to the tendency to create, consciously or unconsciously, rather simplistic binary categories of Norseman and native, too little attention has been paid to the nature of social and economic relations between Scandinavian groups and individuals within Ireland. Most of the plunder taken by raiders in the ninth and tenth centuries comprised livestock and people. The livestock were probably mostly used to supply the armies with food and hides for clothing and equipment, or as mounts for expeditions, but the people were either ransomed back to their communities, if of sufficiently high status, or sold overseas. ${ }^{21}$ The logistics of the slave trade probably require a little more thought than has often been given them. Each warrior was in a position to capture slaves, or receive his share of a joint predation, but it is unlikely that these individuals would carry through the entire exportation process themselves. We should probably consider then that much of the market activity that occurred at longphort sites such as Woodstown consisted of slaves being purchased from individuals or small groups of warriors either by professional traders or, perhaps more likely, by their own commanders. In this way the principle of a distribution of spoils and the practicalities of long-distance commerce could be reconciled. This may suggest that the presence of scales and weights on these sites attests to the practicalities of soldiers' pay and division of spoils rather than mercantile entrepreneurism. The silver itself must have been brought into Ireland by the invaders. If any of it made its way into the hands of native Irish groups it must have done so either through

20 J. Sheehan, 'Silver', in I. Russell and M. F. Hurley (eds.), Woodstown: A Viking-Age Settlement in Co. Waterford (Dublin: Four Courts Press, 2014), 194-221.

21 P. Holm, 'The Slave Trade of Dublin, Ninth to Twelfth Centuries', Peritia, 5 (1986), $317-45$. 
successful assaults on viking encampments or through the purchase of slaves from Irish warriors who had preyed upon their neighbours. ${ }^{22}$

This last point should encourage us to consider the nature of slavery and the transformative nature of the viking engagement in the slave trade in Ireland. Slavery was endemic to Ireland: the cumal, a slave girl, was one of the standard units of value. It is likely that many, perhaps most, households would have owned a handful of slaves who would have helped with the agrarian and household chores. These slaves, however, will have mostly been Irish-born and the households they served in would have been very like those into which they had been born; in language, custom and economy. They will, for the most parts have been recruited through the widespread local warfare which makes up most of the entries in the Irish chronicle record. What changed with the arrival of the vikings was both the nature of the fate of the enslaved and the motivation of the enslavers. There is very little evidence of a slave trade in pre-viking Ireland and most slaves were probably allocated to the households of those who had engaged in the fighting or distributed by the local kings and lords as part of the practice of redistributive chieftaincy that characterised the Irish political system. Cattle and ponies would have been passed on in much the same way. Kings or their kinsmen led predatory raids on neighbouring territories and redistributed the spoils amongst their neighbours. Slaves taken or sold to the Scandinavians, however, would mostly have gone out of the country and found themselves, ultimately, in households or labour gangs where Irish was not the language of the community, where customs, foodstuffs and perhaps even climate and social norms were completely different.

We can compare this to the trans-Atlantic and trans-Saharan slave trade of more recent centuries which transformed the endemic and localised West African slavery, very similar to early Irish slavery, into something far less humane. The other similarity to this modern phenomenon was the way in which the willingness of the foreigners to pay for slaves with exotic and very valuable currency encouraged the development of native polities which engaged in commercial slaving rather than simply supplying their own domestic needs. ${ }^{23}$ This may lie behind the appearance in the later ninth and tenth

22 E. Purcell and J. Sheehan, 'Viking Dublin: Enmities, Alliances and the Cold Gleam of Silver', in Hadley and ten Harkel (eds.), Everyday Life in Viking-Age Towns, 35-60.

23 R. J. Reid, Warfare in African History (Cambridge University Press, 2012), 79-90. For the centrality of slave-raiding in a modern African kingdom, see S. P. Reyna, Wars without End: The Political Economy of a Pre-Colonial African State (Hanover, NH: University Press of New England, 1990). 
centuries of large hoards of silver, ultimately deriving from the HibernoNorse communities, in the territories of some of the more politically active and dominant Irish dynasties such as Mide, northern Brega and the lands of the Cenél Eógain. The opportunities for wealth that this trade provided may also have created the conditions which led to the breakdown of the relative political stability of Uí Néill and Eoganacht hegemonies which had existed at the beginning of the Viking Age, and may explain why even when Irish kings were in a position to snuff out the Hiberno-Norse towns they increasingly declined to do so, from Cerball mac Murecáin's conquest of Dublin in 902, to the capture of Limerick by Mathgamain mac Cennétig in 967 and beyond. Whilst they wished to call a halt to Scandinavian predation on their own lands and the rivalry of the Hiberno-Norse dynasties within Irish politics, they did not wish to kill the goose which laid the silver egg. ${ }^{24}$

\section{Dublin}

The ability of Hiberno-Norse towns to survive even when their ruling dynasties were expelled should encourage us to consider what the political structures of such places were and how they related to kings. Whilst modern scholarship tends to use the term 'king of Dublin' quite freely, its Irish equivalent ri Atha Cliath appears very rarely, and late, in the chronicle record and usually seems to be applied to a ruler who acknowledged another king as his overlord. ${ }^{25}$ More usually, the kings whom scholarship designates as kings of Dublin are simply titled ri Gall, 'king of the foreigners' ${ }^{26}$ This ought to encourage us to consider whether we are correct in seeing their polity as Dublin or whether Dublin was not merely one province that sometimes fell under their sway. Scandinavian polities tended to be somewhat federal in structure with autonomous districts governed by local assemblies and having their own customary law. Kings, leading a largish military household, tended to itinerate between them, spending a few weeks in each before moving on to consume tribute elsewhere. Different provincial assemblies often elected

24 Reid, Warfare in African History, 101-5. AU, i, 417, 483. See also Íslendingabók, Landnámabók, ed. J. Benediktsson (Reykjavík: Hid islenzka fornritafelag, 1986), 32-3, which synchronises the settlement of Iceland with a list of kings ruling elsewhere in Europe including 'Kjarvalr at Dyflinni'.

25 So far as I have been able to ascertain, the first appearance of the term is in 1075 ( $A U$, ii, 27); a notice of the death of Godred Olafsson.

26 The Irish word Gall (pl. Gaill) actually means something slightly more nuanced than its conventional translation 'foreigner'. It derives from Latin Gallus, 'a Gaul', and was used of those deemed to be from continental Europe. Saxons, Britons and Picts were not termed Gaill. 
rival members of the ruling dynasty as king when the succession came into question, leading to protracted periods of civil war. ${ }^{27}$ The dynasty of Ímar [Ivar], which dominated Dublin and perhaps the other Hiberno-Norse towns from the late ninth century onwards, also had strong interests in Britain and perhaps in the Scottish islands, and we are probably being misled by the relative volume of the Irish sources if we assume that Dublin was their principal residence and that the Uí Ímair imperium was ruled from Dublin. Whilst it was undoubtedly a very important part of their kingdom, and its loss over the course of the eleventh century dealt them a fatal blow, the manpower they deployed in the ninth and tenth centuries must have been drawn from a much wider area and the eventual Irish domination of Dublin may have been facilitated by the men of Dublin themselves if they found the presence of the U' Í Ímair king and his retinue somewhat inconvenient and oppressive. ${ }^{28}$ The Isle of Man immediately leaps to mind as a possible major component in this polity. It is the only part of these islands which has so far yielded significant viking ship burials and it plays host to its own distinctive school of very highquality Scandinavian sculpture. A number of eleventh-century 'Dublin' kings are found ruling there after their expulsion from the city, and in the twelfth century it was clear that 'Manx' kings felt they had a claim on Dublin. Man is almost completely absent from our sources during the height of the power of the Uí Ímair and re-emerges as Dublin falls under the dominion of native rulers. ${ }^{29}$ It is, in some sense, the Heart of Darkness of the Irish Sea in the Viking Age. Around it lay parts of northwest England and southwest Scotland that were very late being incorporated into the nascent Scottish and English kingdoms and which for much of the Viking Age were probably component parts of the Uí Ímair imperium, much as Man, Dublin and at least some of the other Hiberno-Norse towns were. ${ }^{30}$

27 S. Brink, 'Law and Legal Customs in Viking-Age Scandinavia', in J. Jesch (ed.), The Scandinavians from the Vendel Period to the Tenth Century: An Ethnographic Perspective (Woodbridge: Boydell Press, 2003), 87-115; S. Brink, 'Legal Assemblies and Judicial Structure in Early Scandinavia', in O. S. Barnwell and M. Mostert (eds.), Political Assemblies in the Earlier Middle Ages (Turnhout: Brepols, 2003), 61-72.

28 For the narrative of the dynasty of Ívarr see B. Hudson, Viking Pirates and Christian Princes: Dynasty, Religion and Empire in the North Atlantic (Oxford University Press, 2005), and C. Downham, Viking Kings of Britain and Ireland: The Dynasty of Ívarr to AD 1014 (Edinburgh: Dunedin Academic Press, 2007).

29 D. M. Wilson, The Vikings in the Isle of Man (Aarhus University Press, 2008).

30 The best account of the Irish Sea as an interconnected set of provinces in this period is D. Griffiths, Vikings in the Irish Sea: Conflict and Assimilation, AD 790-1050 (Stroud: Sutton Publishing, 2010), which includes detailed discussion of patterns of Scandinavian-style burial around the region, including the Manx ship burials, at 72-99. 
What then of Dublin itself, and by analogy perhaps, the other HibernoNorse towns which are less well accounted for in either the chronicle or the archaeological record? The interior layout of the towns is not well known since all lie under modern urban centres and so full plans cannot be drawn out. However, one distinctive feature is clear and that is that wherever it has been possible to investigate the interior, it has become apparent that from the late ninth century onwards regular plots, similar to later medieval burgage plots, had emerged and that the boundaries of these plots remained very stable for several hundred years, even when the buildings within them were replaced or destroyed. During the ninth to eleventh centuries the dominant type of building within each plot was also remarkably stable. This is what has been termed the Dublin 'Type 1' house; a rectangular building with a total floor space of about $40 \mathrm{~m}^{2}$ with a door at each end, one opening onto the street and the other onto the plot, a hearth in the middle, impeding clear access between the doors, and raised sitting and sleeping areas on either side. The tripartite structure of the building was also marked out by a line of roof supports separating the floor space from each of the raised areas. In the rear of the plot there might be a range of secondary building and also metalled or decked pathways leading between buildings and alongside plots that were probably garden beds or small livestock pens. The plots were almost certainly the garths or gardda mentioned in the textual sources which formed the basis for taxation within the town. ${ }^{31}$

When trying to visualise these domestic units we should remember that the vast majority of early medieval buildings had only one room and that therefore collections of detached buildings on a single plot may have fulfilled a range of domestic functions similar to the rooms in a more modern house. Thus we have to wonder whether all members of the household slept on the raised areas of the Type 1 house, or whether the householder and his wife might have had a separate chamber in the yard out back. It is quite likely that the answer to such questions would vary according to the demography and wealth of the household. What we can be fairly certain of is that these domestic units represent the habitations of the Dubliners themselves rather than the itinerant followers of the king. So far, no royal hall or compound

31 R. Boyd, 'From Country to Town: Social Transitions in Viking Age Housing', in Hadley and ten Harkel (eds.), Everyday Life in Viking-Age Towns, 76-9; P. F. Wallace, 'Gardda and Airbeada: The Plot Thickens in Medieval Dublin', in Smyth (ed.), Seanchas, 261-74. For scepticism regarding the equation of gardda with these plots: P. Holm, 'Manning and Paying the Hiberno-Norse Dublin Fleet', in Purcell et al. (eds.), Clerics, Kings and Vikings, 76. 
has been located by the archaeologists though it is widely speculated that such a site might have lain on the site of the present-day Dublin Castle. This seems quite likely, though we should not exclude the possibility that the royal compound lay outside the town, as the Earl's hall at York did. Were a royal compound to exist, it would probably not contain enough space for the whole of the retinue of the king and, by analogy with later Scandinavian, Irish and Welsh practice, it is likely that some of the king's soldiers would be billeted upon townsmen. In some cases these might have been people with whom they had good social and perhaps familial links, in other cases this might have been a duty which householders, particularly those with teenage daughters, might have resented. A local ri Atha Cliath with a much smaller retinue who depended on the Dubliners themselves for his military support might have been more welcome to the locals.

We have no textual evidence for the social organisation of Dublin or any of the other Hiberno-Norse towns in this period, but a useful piece of comparative material survives in a text from the very late tenth century known as the Cambridge Thegns' Guild. ${ }^{32}$ Like Dublin, Cambridge was a settlement founded by a viking army in the ninth century and gradually came to be incorporated into the English kingdom as its townsmen accepted the overlordship of the West-Saxon kings who were in the process of uniting the country. In crude terms its basic history was broadly similar to that of Dublin or Limerick in the period between the mid-ninth and early eleventh centuries. The Cambridge document is very short and was written onto a blank leaf of a Gospel book between 970 and 999:

Here in this writing is the declaration of the enactment which this fellowship has determined in the thegns' guild in Cambridge. Firstly, that each was to give to the others an oath of true loyalty, in regard to religious and secular affairs, on the relics; and all the fellowship was ever to aid him who had most right. If any guild-brother die, all the guildship is to bring him to where he desired, and he who does not come for that purpose is to pay a sester of honey; and the guildship is to supply half the provisions for the funeral feast in honour of the deceased; and each is to contribute two pence for the almsgiving, and from it the fitting amount is to be brought to St Athelthryth's. ${ }^{33}$ And if then any guild-brother have need of his fellows' help and it is made known to the reeve of the nearest guild-brother - unless the guild-brother himself be at hand - and the reeve neglects it, he is to pay one pound. If the

32 Diplomatarium Anglicum Aevi Saxonici, 610-13; translated in EHD, i, 557-8.

33 Probably the monastery at Ely, fourteen miles north of Cambridge (one might like to compare the relationship between Dublin and the church at Swords in the eleventh century). 
lord neglects it, he is to pay one pound, unless he is engaged on the necessary business of his lord, or is on a bed of sickness. And if anyone kill a guildbrother, nothing other than eight pounds is to be accepted as compensation. If the slayer scorn to pay the compensation, all the guildship is to avenge the guild-brother and all bear the feud. If then one avenges him, all are to bear the feud alike. And if any guild-brother slays a man and does it as an avenger by necessity and to remedy the insult to him, and the slain man's wergild is 1200 [shillings], each guild-brother is to supply half a mark to his aid; if the slain man is a ceorl, two ores; if he is Welsh, one ore. If, however, the guildbrother kill anyone foolishly and wantonly, he is himself to be responsible for what he has done. And if a guild-brother slay a guild-brother through his own folly, he is himself to be responsible towards the kindred for the offence he has committed, and to buy back his membership of the guild with eight pounds, or he is to forfeit for ever fellowship and friendship. And if a guildbrother eats or drinks with the man who slew his guild-brother - unless it be in the presence of the king, or the bishop of the diocese, or the ealdorman ${ }^{34}-$ he is to pay one pound, unless he can deny with two of his bench-fellows that he knew him..$^{35}$ If any guild-brother insults another, he is to pay a sester of honey, unless he can clear himself with two of his bench-fellows. If a retainer draws a weapon, the lord is to pay one pound, and the lord is to get from him what he can, and all the guildship is to assist him to recover his money. And if a retainer wound another, the lord is to avenge it, and all the guildship together; that - no matter what advocacy he seek - he shall not keep his life. And if a retainer sits within the aisle he is to pay a sester of honey. And if anyone has a fotsetla, ${ }^{36}$ he is to do the same. And if any guild-brother dies outside the district, or is taken ill, his guild-brothers are to fetch him and bring him, dead or alive, to where he wishes, on pain of the same fine which has been stated in the event of his dying at home and a guild-brother failing to attend the body. And the guild-brother who does not attend his $\mathrm{m}$... [lacuna in the manuscript] is to pay his sester of honey.

As can be seen, the Cambridge Thegns' Guild is an association of equals, who own property and might have armed retainers and servants. The references to the aisle, and to bench-fellows, suggests that the Guild had a commonly held drinking hall, something which was a standard feature of guilds in this period. Such a guild hall at Dublin may even be mentioned by Gerald of Wales. ${ }^{37}$ The Guild served, to some extent, to provide the urban dwellers with the

34 Each of these dignitaries is recognised as being able to 'impose peace' within their presence.

35 That is, that he sat down to eat with him not knowing him to be the killer of his guild-brother.

36 A personal attendant.

37 Expugnatio, 67-9. 
same kind of protection a kinship network would provide in the rural society that was more normal at the time. The emphasis put on vengeance and burial is particularly noteworthy. What I would suggest is that this short text gives us an impression of the kind of 'constitution' that would have bound the householders of Dublin, and the other Hiberno-Norse towns, together. In 917 the 'army that belonged to Cambridge' chose Edward the Elder 'as their lord and protector' when he led his forces into East Anglia and it is very likely that the men of Dublin behaved in like fashion that same summer when Sitriuc, grandson of Ímar, arrived at their gates. ${ }^{38}$ The corporate interests of each viking town would be governed by such guilds with regular meetings to hear court cases and decide on policy at established assembly sites like the Thingmote across the Poddle from the town of Dublin, probably located somewhere near where the Olympia theatre stands today. It would be at such assembly sites that kings would be acclaimed. ${ }^{39}$

\section{The 'Hiberno-Norse'}

When viking raids began in the eighth century we can clearly distinguish Scandinavian raiders from native Irish, but as time went by this distinction becomes less simple. By the time of the Anglo-Norman invasion in the later twelfth century some Norse kindreds might have been established in Ireland for over 300 years. Given that popular accounts of invasions and migrations often take a very simplistic, even irrational, view of ethnic identity, there is a need to re-examine what it meant to be Hiberno-Norse. In modern scholarship, 'ethnicity' refers to social identity whilst 'race' refers to biological identity. These terms are often confused in public discourse, with 'ethnicity' simply being used as a polite alternative for 'race'. The easiest way to get to grips with the distinction is to think of an individual who has been adopted abroad in infancy, such as one of the many Chinese or African orphans who have been coming to Europe and North America in recent times. They will grow up with the social attitudes of their adopted parents and the community they live in, even though they do not share their biological heritage. The biological heritage is often referred to as 'race', but this term is problematic: the old idea that there were discrete races is not founded on good

38 Anglo-Saxon Chronicle 5, MS C, ed. K. O’Brien O’Keeffe (Woodbridge: Boydell Press, 2000), s.a. 917 A: $A U$, i, 435.

39 S. Duffy, 'A Reconsideration of the Site of Dublin's Viking Thing-mót', in T. Condit and C. Corlett (eds.), Above and Beyond: Essays in Memory of Leo Swan (Bray: Wordwell, 2005), $351-60$. 
science, since most population groups have undergone considerable mixing throughout history and the variation within and between them cannot be scientifically defined. Furthermore, in many historical texts, such as the Bible and much medieval literature, the terms generally translated into modern English as 'race' referred to unilineal descent, usually in the direct male line, taking no account of the ancestry of all the mothers. This is the case when we talk about early Irish dynasties such as the Uí Néill or indeed the Uí Ímair. Unilineal descent can of course have little relationship to either one's ethnic identity or one's physical appearance. A useful term that might replace the popular usage of race is 'phenotype', which means genetically-determined physical appearance. ${ }^{40}$

These issues are of particular significance for the Viking-Age Scandinavian diaspora. To what extent and in what sense did the populations of the colonies remain Scandinavian over time? In multicultural metropoloi like twentyfirst-century Dublin, London or New York, it is very easy to think of cultural choices as individual, personal and varied. In such societies generational differences are often as great as inherited differences. The early medieval world was very different. It was overwhelmingly rural. There were no towns in Ireland before the Norse arrived, and even on the eve of the Anglo-Norman invasion only a tiny percentage of the population lived in towns. The same was true in Scandinavia. In rural societies men could usually only marry if they held enough agricultural land, either in allodial, inherited, tenure, or in some sort of relatively secure tenancy. This meant that most men lived close to their patrilineal brothers and cousins, who would be potential heirs to their land if they died without issue. There was no monetised economy and most material culture, from clothes and tools to houses and furniture, was made locally either by members of one's own household or by neighbours. A very small amount of relatively exotic material might filter down through society from chieftains who engaged in gift-exchange, raiding and perhaps some small-scale trade, and who may have patronised a very small number of specialist craftsmen. Wives were also often cousins or at least neighbours. This meant that in times of stability social choices were limited and individuals had little scope to be culturally innovative. Tradition - that is ideas and stories handed down the generations - dominated ideas of identity.

40 A German colleague describes her adopted sister as 'phenotypically Chinese'. The woman in question resembles the Chinese stereotype physically and draws her biological heritage from China, but has grown up in Germany, in a German-speaking family, so her attitudes, prejudices and tastes reflect her German ethnicity. 
When groups of individuals engaged in long-distance migration, however, as the early viking raiders and invaders did, things were different. The first generation of warriors to cross the sea had grown up in conservative societies. They were now encountering new sets of challenges without their elders on hand to advise them on how to deal with them. For the most part, ships' crews were entirely male and reflected a relatively limited age profile, perhaps between about fourteen and thirty years of age, with a bias towards the younger end of the scale. From a very early stage these groups may have begun to recruit locals into their forces. We have seen that slave-raiding was a major part of the activities of viking expeditions and it is likely that the majority of slaves taken were younger women and children. Whilst women, particularly those whose virginity had been preserved, could probably be sold on for a very high premium, it is quite likely that some of the male children might have been retained as personal servants, to cook, clean weapons and so forth. As happens, notoriously, in many militias in central Africa today, such boys might graduate to become child soldiers. ${ }^{41}$ This brings us back to questions of ethnicity and race. When discussing Chinese babies adopted by European couples it is easy to see that the children will retain none of their biological parents' ethnic traits, but what of someone who moves from one ethnic community to another aged eight or twelve? To what degree will he retain the social identity of his natal home? The answer is probably entirely situational; down to the individual himself or the attitude of his new messmates. Perhaps one viking warrior slaps his boy if he catches him speaking Irish or talking about his family, while another shows curiosity or empathy. In the end, however, the corporate identity of the group in which the young person continues to mature, be it a household or a ship's crew, will be the main factor governing his daily speech, his diet and his clothing choices. By the time he is in his twenties he will be a viking, regardless of the circumstances of his birth. Irish, English and continental annals make it quite clear that some viking fleets and armies remained on the move for decades and life histories like those just hypothesised were probably a significant factor in allowing them to recruit fresh soldiers. Such conditions, of course, play havoc with attempts to identify vikings or their descendants using genetic markers. Recently excavated warrior burials from the earliest phases of viking Dublin contain individuals, some of whom were probably raised in Scandinavia and

41 A. Honwana, Child Soldiers in Africa (Philadelphia: University of Pennsylvania Press, 2006); M. A. Drumbl, Reimagining Child Soldiers in International Law and Policy (Oxford University Press, 2012). 
others almost certainly in Ireland or western Scotland. These young men may have begun their career in the fashion just described..$^{42}$

The dynamics of viking armies on the move were undoubtedly different from those of settled Hiberno-Norse communities. One major factor underpinning the development of the urban communities was necessarily their relationship with their immediate hinterlands. In the early days, when the longphuirt were simply pirate camps, local people probably fled from their occupants who were left to steal what they could find. Over time, however, tributary relations (doubtless still viewed as predation) will have developed, and then ultimately, where the camps became towns, a sense of mutual obligation will have arisen. The underlying structures for such a relationship were already in play in Irish society. Many túatha regularly paid tribute to neighbouring kings or indeed to a king of their own who spent little time among them. The hinterland of Dublin, which came to be known in Irish as Fíne Gall, the 'kindred of the foreigners', seems to have been constructed out of two pre-existing tuatha, both lying north of the Liffey: Saithne, in the south, and Túath Tuirbe to the north, divided from one another by the Broad Meadow Water. ${ }^{43}$ These had originally been component parts of the kingdoms of southern Brega. No detailed accounts survive of how these territories evolved from oppressed tributaries to suburban hinterlands but the transition doubtless happened. Immediately south of Dublin the local tuatha seem to have remained under the control of the Uí Dúnchada dynasty, which continued to compete for the over-kingship of the Láigin until at least 1003, but it is hard to believe this would have been possible without some level of collaboration. By the twelfth century, and perhaps long before, some farms in the area were owned by men with Norse names though Irish appears to have remained the most widespread language. ${ }^{44}$ Whether individual Dubliners bought land from their Irish neighbours or whether the tribute of the territory was shared out into plots, as happened with the viking-founded towns in Russia at about the same time, is unclear. ${ }^{45}$ It is very likely that intermarriage occurred and some land may have changed hands in such transactions. The regulations of the Cambridge Thegns' Guild, cited above, mention a guildbrother having a reeve and this would seem to imply that the townsmen

42 L. Simpson, 'A Viking Warrior Grave from Dublin', in Clarke and Johnson (eds.), Vikings in Ireland and Beyond, 142-5.

43 MacCotter, Medieval Ireland, 165-6.

44 J. Bradley, 'The Interpretation of Scandinavian Settlement in Ireland', in Bradley (ed.), Settlement and Society in Medieval Ireland, 49-78.

$45 \mathrm{~J}$. Blum, Lord and Peasant in Russia: From the Ninth to the Nineteenth Century (Princeton University Press, 1961), 29-42. 
might, or perhaps normally would, own rural estates. The basic taxable unit in rural Ireland in this period, the baile (ancestral to the modern townland), may well have been transferred to Hiberno-Norse landlords who initially resided in Dublin and simply lived off the agricultural renders, but who may have increasingly taken an interest in managing their estates. At the same time inhabitants of these territories may have increasingly entered the town to avail themselves of market opportunities and relationships of fosterage may even have been entered into across the ethnic divide. Bilingualism will have presumably become increasingly common as time went on. ${ }^{46}$

Had the Norse simply left Scandinavia in the ninth century, settled in Ireland and turned their backs on their homeland we might have expected a more rapid assimilation and adoption of the Irish language. The people of the rural hinterland, the servants and probably many of the wives of the townsmen, would have spoken Irish as their first language. Norse, however, remained useful as long as commercial relations underpinned the prosperity of the towns. Irish was not a language of commerce, whilst Norse was spoken widely in the ports of the North Sea and the Channel littoral and beyond. It is probably also the case that Hiberno-Norse towns continued to attract fresh migrants from Scandinavia seeking their fortune either as merchants or mercenaries, or as both. Nonetheless by the end of the tenth century we begin to see Gaelic names appearing even in the ruling dynasty and this, together with the veneration of Gaelic saints, probably signals the emergence of a distinctive Hiberno-Norse identity. To some extent the break-up of the Uí Ímair imperium may have reflected the emergence of distinct hybrid cultures in its different territories, as many who shared a common patrilineal descent from viking raiders of the ninth century came to be thought of as more Irish or English. In modern scholarship we use the terms HibernoNorse and Anglo-Danish to describe these new hybrid colonial cultures: such terms were alien to the men and women of the tenth and eleventh centuries but the underlying distinctions would have been very apparent to them. In Rouen and Bayeux the Normans were undergoing a similar process, as were the Rus in Novgorod and Kiev. What we do see throughout the Scandinavian diaspora in this period is the reinforcing of certain specific cultural features, be it toy ponies of remarkably similar design across the whole of the viking world, images reflecting the story of Sigurðr the Dragon-slayer, or the spread of the innovative Ringerike art style. In some ways explicit appeals to a common stock of Scandinavian signifiers appear to have become more prevalent

46 For bailte see MacCotter, Medieval Ireland, 45-87. 
in the decades around the year 1000, when colonial communities were nativising apace. ${ }^{47}$

One factor intimately connected with this nativisation was the conversion to Christianity. There are no dramatic conversion narratives surviving for the Hiberno-Norse like those recounted in Bede's Historia Ecclesiastica or Muirchú's Life of Patrick. Indeed Irish sources tell us of no such conversion. In the second quarter of the tenth century, three kings of the dynasty of Ívarr were pressured into undergoing conversion ceremonies by West-Saxon kings in England but the extent to which these events contributed to any real Christianisation is unclear. ${ }^{48}$ The use of the term geinte ('heathens') to describe the Norse in Ireland declines rapidly in the Irish chronicles in the same period. Olaf Cuarán, the dominant figure in the mid-tenth century, retired to Iona, where he died, after his defeat at the Battle of Tara in 980, and his son Sitriuc went on pilgrimage to Rome in $1028 .{ }^{49}$ Other evidence for Christianisation comes in the use of Irish names for adult Norsemen from the last quarter of the tenth century. Some of these may not indicate that the bearer is Christian, though it seems likely, but others, compounds of Mael and Gilla with a saint's name, are explicitly so and there is some indication that the Gilla names, which seem to occur earliest and most frequently amongst Hiberno-Norse and Hebridean individuals, may even have been coined in this context. ${ }^{50}$ The conversion of the Uí Ímair rulers, however, need tell us little of the confessional history of the bulk of Hiberno-Norse individuals. Many of the inhabitants of the Hiberno-Norse towns, servants, wives and hostages, must have been born and raised in Christian households and may have continued to practise and even proselytise in their new homes. Many a Christian hand may have rocked a pagan cradle, and during the period when Dublin was ruled by the Leinster kings Cerball and Augaire (902-17) there must have been social, if not political, pressure to accommodate Christianity. Dublin seems not to have gained its own bishop until late in Sitriuc Olafsson's reign but its location on the south side of the Liffey will have put it, at least notionally, in the cure of the bishops of Uí Dunchada; the obits of these prelates, based at Tallaght, are noted in 915, 964, 966 and 968. Within the tributary territories north of the

47 D. McAlister, 'Childhood in Viking and Hiberno-Scandinavian Dublin, 800-1100', in Hadley and ten Harkel (eds.), Everyday Life in Viking-Age Towns, 92-4; L. Abrams, 'Diaspora and Identity in the Viking Age', Early Medieval Europe, 20.1 (2012), 23-4, 29-30. 48 L. Abrams, 'The Conversion of the Scandinavians of Dublin', ANS, 20 (1997), 1-29.

49 Dumville, Churches of North Britain, 37; Ann. Tig., 342, 368.

50 L. Abrams, 'Conversion and the Church in Viking-Age Ireland', in Sheehan and Ó Corráin (eds.), Viking Age in Ireland, 5. 
Liffey episcopal obits are noted for Lusk in $907,909,929$ and $967 .{ }^{51}$ In the early eleventh century, shortly before Sitriuc's expedition to Rome, we have an obit for a bishop of Swords, the Columban church patronised by the dynasty of Ívarr. The first bishop based in Dublin, appears to have been Dúnan, who died in $1074 .{ }^{52}$

Sitriuc Silkenbeard (d. 1042) was the last significant ruler to be based in Dublin. By his time the city had far surpassed all the other Hiberno-Norse towns with Limerick, its closest rival, having been securely within the Dál gCais kingdom of Thomond since his childhood. He should probably also be compared with some of his Scandinavian peers in the actions he took to promote a more 'European' character to his kingdom. In the latter part of the 990 s he began to mint his own coins, the first in to be minted in Ireland. They closely followed the model of English contemporary coinage, and his desire to produce coins with his own name on them (since foreign coins had long been in circulation) may reflect the need of kings based primarily in Dublin, and lacking a British hinterland from which to draw troops, to supplement the levy of the townsmen with mercenary forces. Elsewhere in the world, from the ancient Aegean onwards, coinage frequently first appeared hand-in-hand with the payment of mercenaries, and in the literary accounts of Sitriuc's great showdown with his father-in-law Brian Bórama at Clontarf his reliance on troops drawn from outwith his own lordship is always emphasised. A mercenary army, pilgrimage to Rome, and the establishment of an episcopal seat in his capital marked Sitriuc out as a modern European ruler. ${ }^{53}$

A major problem is knowing to what extent the history of Dublin, so well documented both by medieval texts and archaeological excavation, can be used to understand the other Hiberno-Norse towns. Limerick seems to have shared a broadly similar, if less auspicious, history in the tenth and eleventh centuries but has so far delivered far less archaeological evidence. Its name, derived from Loch Luimnech, the broad island-dotted stretch of water where the River Fergus joins the lower Shannon now dominated by Shannon International Airport, suggests that the present site is a late development. How late is difficult to say, and no site comparable to Woodstown has so far

51 C. Etchingham, Church Organisation in Ireland AD 650 to 1000 (Naas: Laigin, 1999), 483.

52 AFM, ii, 805, 907. Note that in recording Dúnan's death $A U$, ii, 27 makes no mention of Dublin, describing him instead as Archbishop of the Gaill. This may indicate a wider remit in the Irish Sea region: A. Woolf, 'The Diocese of the Sudreyar', in S. Imsen (ed.), Ecclesia Nidrosiensis, 1153-1537 (Trondheim: Senter for middelalderstudier, 2003), 171-2.

53 D. Schaps, 'The Invention of Coinage in Lydia, in India, and in China', XIV International Economic History Congress (Helsinki, 2006), session 30, www.helsinki.fi/iehc2006/ papers1/Schaps.pdf. 
been identified in Loch Luimnech. It is hard to demonstrate, on the basis of either archaeological or textual evidence, that the smaller towns of Cork and Wexford existed prior to the later eleventh century and they may belong entirely to the period when the Hiberno-Norse operated within native Irish kingdoms. Elsewhere re-analysis of earlier finds and more critical readings of the textual evidence continue to modify our view of the subject. ${ }^{54}$

54 S. H. Harrison and R. Ó Floinn, Viking Graves and Grave-Goods in Ireland (Dublin: National Museum of Ireland, 2015) reviews all of the cemetery evidence recovered in the last three hundred years, whilst C. Etchingham is currently working on a full-length monograph updating his insightful volume Viking Raids on Irish Church Settlements in the Ninth Century (Maynooth: An Sagart, 1996). 